\title{
Writing Truth to Power: Jonas Khemiri's Work in Stockholm and New York
}

\author{
Helena WulfF \\ Department of Social Anthropology \\ Stockholm University, SE-10691 \\ Stockholm, Sweden
}

SUMMARY This article explores the work of Swedish writer Jonas Hassen Khemiri, of partly Tunisian origin, in terms of cultural translation and comparison between Stockholm and New York. I discuss three texts by Khemiri in different writing genres: first, an open letter to Sweden's Minister of Justice, which went viral in 2013 and was also published in the New York Times, about racial profiling in Stockholm; second, the play I Call My Brothers, written in response to a failed terrorist attack in Stockholm in 2010 and staged in New York; third, the award-winning novel Everything I Don't Remember (2016b) selected as a 2016 Times Literary Supplement Book of the Year by Joyce Carol Oates. Why would Khemiri's open letter, play, and novel that address new issues of power, stereotypes, and physical appearance in Sweden matter in the United States, with its deep-rooted diversity? The conclusion is that the international success of these pieces has nothing to do with Sweden or an interest in Swedish contemporary life but can be understood as local variations on the global themes of terrorist crimes and racial profiling. [migrant writing, fiction, journalism, Jonas Hassen Khemiri, Sweden]

The following quotation comes from a New York Times article titled "Sweden's Closet Racists" by the Swedish writer Jonas Hassen Khemiri, the son of a Tunisian father and a Swedish mother. ${ }^{1}$

We remember the shame and the slights.

Being 6 years old and walking toward passport control with Dad, who has sweaty hands, who clears his throat, who fixes his hair and shines up his shoes on the backs of his knees. All the pink-colored people are let by. But our dad is stopped. And we think, maybe it was by chance, until we see the same scene repeated year after year.

Being 7 and starting school and being told about society by a dad who was terrified even then that his outsiderness would be inherited by his children. (Khemiri 2013a)

The quotation continues with Khemiri's father saying: “'When you look like we do, you must always be a thousand times better than everyone else if you don't want to be refused.'" This triggers Khemiri's decision "to become the class's most studious nerd, the world's biggest brown-noser" (Khemiri 2013a). The article was a translation of an open letter Khemiri wrote to Sweden's Minister

Anthropology and Humanism, Vol. 44, Issue 1, pp 7-19, ISSN 1559-9167, online ISSN 1548-1409. (C) 2019 by the American Anthropological Association. All rights reserved.

DOI: 10.1111/anhu.12227. 
of Justice, Beatrice Ask, in 2013 (Wulff 2018). It was prompted by her defense on the radio of a new racial profiling project in Stockholm, called REVA, an intensified effort to find undocumented migrants. ${ }^{2}$ The article moves on to portray Khemiri as a young adult. He talks about himself as "we":

We stopped playing basketball and started studying economics. One day we were standing outside the Central Station, jotting something down in a notebook (because even if we were studying economics, we had a secret dream of becoming an author).

Suddenly someone appeared, a broad man with an earpiece asked for ID, pushed our arms up and dragged us toward the police van.

Apparently we matched a description. Apparently we looked like someone else.

We sat in the van for 20 minutes. Alone. (Khemiri 2013a)

Khemiri is humiliated. Then suddenly he is free to go. Having checked that he really is the person he is claiming to be, the plain-clothed policeman opens the door, and says, "You can go now," without apologizing, without explaining. Khemiri takes some comfort in the fact that "others have it much worse ... After all, I was born here. I know the language. I am not threatened with deportation" (Khemiri 2013a).

But the experience of being a suspect in one's own country is one side of contemporary Sweden. This is happening in a country that still claims an ethnically inclusive policy. So how does this compare with other countries? In my literary anthropological study of migrant writing in Sweden, focusing on fiction and journalism, the comparative perspective accentuates diversity, and not only linguistic diversity but certainly cultural diversity. More often than not, this is cultural diversity as a contested issue, including experiences of exclusion and even racism. Anthropology is by definition a comparative discipline. Andre Gingrich has argued that comparison in anthropology is "the field's third main methodological inventory, together with ethnographic fieldwork and historical anthropology" (Gingrich 2015:411). Yet unlike fieldwork and historical methods, Gingrich points out "comparative methods went through much more contested times in anthropology, before they became widely recognized again as the third key methodological element in the anthropology of the globalized present." Now there is a "new pluralism of comparative procedures" such as "binary, regional, temporal, distant, and fluid versions of comparison" (ibid.).

In this article I explore the work of Jonas Hassen Khemiri, celebrated both in Sweden and internationally, in terms of binary comparison. As Khemiri's work has been recognized especially in New York, an analysis of it entails considering its role in Stockholm and in New York. I will discuss the following three of his texts in different writing genres: 1) the open letter to Sweden's Minister of Justice, originally published as "Bästa Beatrice Ask" ("Dear Beatrice Ask"; Khemiri 2013b) in the major Swedish daily Dagens Nyheter, a letter that went viral on a massive scale; 2) the play I Call My Brothers (2016a; Jag ringer mina bröder 2012); and 3) the award-winning novel Everything I Don't Remember (2016b; Allt jag inte minns 2015b), chosen as a 2016 Times Literary Supplement Book of the Year by Joyce Carol Oates. The play I Call My Brothers, which began as an essay for Dagens Nyheter (Khemiri 2010), was a reaction 
to a failed suicide attack in Stockholm in December 2010, when a car bomb only killed the bomber. This attack is not to be confused with the terrorist attack that took place in April 2017, killing five pedestrians in the city center of Stockholm. The essay was later published as a novella in a booklet (Khemiri 2012). ${ }^{3}$ More significantly for our purposes here, the play has been translated into English (as well as numerous other languages) and performed in New York (among many other places outside Sweden). This is a case of comparison in tandem with translation-linguistic as well as cultural translation. It is also in line with what Ulf Hannerz has identified as creative translation, the type of translation that is "to be responded to in aesthetic and intellectual terms both as a reflection of the original work and as a work in its own right" (Hannerz 1993:45).

Khemiri is undoubtedly one of the most prominent, prolific, and versatile writers in Sweden today. Here I am nevertheless searching for an understanding of his international impact. Why would an international audience take an interest in what is happening in Sweden, this admittedly small country "up North"? Why would Khemiri's letter, play, and novel, addressing new issues of power, stereotypes, and physical appearance in Sweden, matter in the United States with its overall and historic diversity? Or, why be of interest anywhere else?

\section{Locating This Literary Study}

Before considering Khemiri's career, and these three cases reporting on contemporary Sweden, let me provide some context in more detail. Literature has been acknowledged by anthropologists as a source of cultural knowledge to some extent for as long as the discipline has existed, but this has intensified during the last decades. There are now quickly expanding anthropologies of literature and writing, and journalism has also attracted anthropological attention (Wulff 2017). At stake is, of course, literature and writing in relation to society and culture. As to methodological strategies in this approach, they cannot be limited to traditional anthropological participant observation and fieldwork. For my study on migrant writing, I do some participant observation at public events such as literary festivals but rely mainly on in-depth interviews and textual analysis. Media and Internet appearances by the writers are also useful. A few years ago, I was invited to participate as a speaker with Jonas Hassen Khemiri on the panel "Ethnography and Fiction" at Stockholm University, organized by anthropology students and my colleague Shahram Khosravi. I conceptualize this, and other social events where I meet the writers and do participant observation with them, in terms of Sherry Ortner's notion of "interface ethnography," referring to the fact that "most relatively closed communities have events where they interact with the public" (Ortner 2013:26). This was my approach in my previous study on writing as craft and career among contemporary Irish fiction writers (Wulff 2017).

The theoretical framework of this study combines literary theorist David Damrosh's (2003) ideas on world literature as the circulation of literary work from national to global contexts with the sociologist Howard S. Becker's (2008) ideas on art worlds as social worlds-including not only writers, but also publishers, editors, agents, critics, and readers (cf. Wulff 2017). One line of inquiry is 
the making of a contemporary writer's career in Sweden, covering issues such as competition and collaboration, breakthrough, and reputation (cf. Bourdieu 1993). Literary scholarship on migrant literature in Sweden, especially by Svedjedal (2013) and M. Nilsson (2010,2012), informs my study. This accentuates the discussion around the concept of "migrant" literature by literary scholars (such as Wendelius 2002 and Gröndahl 2007). Rather than identifying "migrant writers" only, my study includes the texts, fiction, and journalism dealing with migrant experiences written both by writers born in Sweden and by those who have moved to Sweden.

\section{A Swedish Writer and Public Intellectual}

Khemiri was born in 1978 in Stockholm, which is also where he went to school. His first publication was an article about a roadblock in Palestine published in Dagens Nyheter in 1999. It was based on observations during a trip he had made to the Middle East. He then worked in a clothes shop in New York for a while and went on to finish his first book manuscript, a novel. A number of publishers were interested in it but suggested revisions that Khemiri did not appreciate. He studied comparative literature at Stockholm University and international economics at the Stockholm School of Economics. He was eventually offered an internship at the United Nations in New York. By then he had sent his second manuscript to the Stockholm publisher Norstedts, where he felt most appreciated. His debut novel Ett öga rött (One Eye Red) was published in 2003. Khemiri's (2019a) English language web page notes that this book is a "tour de force of stylistic bravado and narrative inventiveness that frames the experience of a young man's alienation in a way that is at once humorous and painful." This breakthrough novel became iconic among young adults in Sweden. It is a story about Halim who "has his own plan: he will become Sweden's most powerful wog revolutionary. A sultan of thought who cracks the codes and gets the prettiest girls" (Khemiri 2003, back cover, my translation). He is not doing very well at school, he misses his deceased mother, business in his father's store is slow, and Swedish society does not seem to want to include them. The novel was made into a play and a film. Since then, Khemiri has been a full-time writer. He has received numerous awards.

By now he has written six books and six plays, in addition to a number of short stories and opinion pieces in newspapers and magazines. A short story titled, "As You Would Have Told It to Me (Sort Of) if We Had Known Each Other Before You Died" (2017a, translated by Rachel Willson-Broyles), was published in the New Yorker in 2017. Like many productive writers, his work is divided into a rhythm of carefully guarded "silent writing periods," when he declines invitations and public appearances, mostly for promotion of new books (cf. Wulff 2017 on the rhythms of writing in Ireland). When Khemiri has finished whatever project he is working on, he gets out in public and lectures in Swedish, English, or French to libraries, festivals, museums, and universities. He also speaks at jails and prisons, not only in Sweden but across Europe and the United States. These appearances are very popular. He is a great performer and an eloquent speaker with a natural ability to relate to different audiences. 
He also comes across very well on television, the radio, and in YouTube clips. It is often forgotten that contemporary writers must be media savvy to make it as authors. It is taken for granted that they are effective advocates for their work in various media. This was not necessarily the case in the past when a writer's career only depended on what, when, and where they published their texts, not if they had a charismatic personality.

Among Swedish contemporary writers, Khemiri is one of the most popular public figures. This evokes envy among some of his lesser known and less successful colleagues, especially those of his generation and of migrant backgrounds. They do not necessarily have the same strong stage personality that Khemiri has, or are simply uncomfortable with public exposure. This does impact negatively on their careers as writers. This envy has come up during conversations I have had with some of these other writers, one of them even referred to Khemiri as "the boot-licker." When Khemiri's novel Everything I Don't Remember was nominated for the distinguished Swedish literary August Prize in 2015 - which it was awarded-writer and journalist Patrik Lundberg (2015), who was adopted to Sweden from South Korea as a baby, wrote a satirical column in the Swedish tabloid Aftonbladet in the form of an open letter to Khemiri, a satire of his letter to the Minister of Justice. ${ }^{4}$ In the column, which can be analyzed as a testimony to Khemiri's success in Sweden, Lundberg (2015) suggests that Khemiri should take on Lundberg's skin and experiences for a while in order to learn what it is like to compete with Khemiri. Lundberg writes (my translation): "You have just released a book. This means that you are everywhere. But you are everywhere all the time. Perhaps you don't know. Other writers talk about you. About how you kind of overshadow all your colleagues." As far as I am aware, Khemiri never replied to this satire, at least not in public. There was some Twitter defense of him by other writers. The satire seems to have been regarded as unfair and distasteful. From Lundberg's point of view, he, too, had grown up in Sweden, was a writer, and was not traditionally Swedish looking either but experienced being overshadowed by Khemiri.

I will come back to Khemiri's original open letter to the Minister of Justice from 2013, which is a clear example of Khemiri's opinion pieces. Another example of his opinion writing is a partly fictionalized conversation between Khemiri and his 4-year-old son, who sees a newspaper picture of a Nazi demonstration and asks about it. The conversation was titled "What are Nazis, Daddy?" ("Vad är nazister, pappa?" 2017b). Prominently placed in Dagens Nyheter in September 2017, it was written in response to a Nazi demonstration that took place in Gothenburg in connection with the renowned Gothenburg Book Fair. This annual event is the major literary festival in Scandinavia (and second in size in Europe after the Frankfurt Book Fair) attracting about 100,000 visitors. But the Gothenburg's Festival's special status has been tainted by the controversial presence of a right-wing newspaper Nya Tider (New Times). Because of this, hundreds of writers and journalists, Khemiri among them, boycotted the Gothenburg Book Fair in 2017. Instead he wrote this opinion piece where he explains what Nazis are to his son. This piece and the open letter represent Khemiri's work as a public intellectual. Considering the public role of writers and intellectuals, Edward Said (2010:24-25) observed that "writers have a separate, perhaps even more 
honorific, place than do intellectuals" as they are often seen with a certain scorn. Said writes: "Yet during the last years of the twentieth century the writer has taken on more and more of the intellectual's adversarial attributes in such activities as speaking the truth to power, being a witness to persecution and suffering, supplying a dissenting voice on conflicts with authority" (my italics) (ibid.). This is exactly what Khemiri does in his letter to the Minister of Justice and in his piece about Nazis in Sweden. His experiences of having a partly Tunisian origin and appearance in Sweden leads Khemiri to write truth to power. He expresses eloquently what is there but has not previously been formulated in such a forceful way. Khemiri's strong political engagement also comes forth through a creative writing workshop that he is running for undocumented migrants in Sweden.

\section{Open Letter Goes Viral}

I now move on to the open letter. The original version in Swedish was published on March 13, 2013. Again, it went viral immediately, breaking the record for most shared ever articles in Swedish. It was shared 180,000 times, mostly on Facebook and Twitter with the hashtag \#bästabeatrice. There, people told their stories of discrimination and racism. The letter became international news on Al Jazeera and other news sites. In April, it was translated from Swedish into English by Rachel Willson-Broyles and published in the New York Times and International Herald Tribune. It did not take long for the letter to appear in journals in French, Italian, German, and Finnish. In the end it was available in twenty languages, including Chinese, Urdu, and Japanese. The New York Times version that I quote above opens with an invitation to the blond and blue-eyed Minister of Justice to try on Khemiri's body for a while:

Welcome to my body. Make yourself at home. From now on, we share skin, spine and nervous system. Here are our legs, which always want to run when we see a police car. Here are our hands, which always clench into fists when we hear politicians talk about the need for stronger borders, more internal ID checks, faster deportation of people without papers (Khemiri 2013a).

And it continues:

On March 7, the minister told a nationwide audience: "There are some who have been previously convicted and feel that they are always questioned, even though you can't tell by looking at a person that they have committed a crime."

It was an interesting choice of words - "previously convicted." Because that's exactly what we are. All of us who are guilty until proved innocent. We Swedes who do not fit the outdated blond, blue-eyed stereotype of what a true Swede should look like. We whose personal experience makes us doubt our country's international reputation of being a paradise, with equal opportunities for everyone (ibid.).

Khemiri's comment that "personal experience makes us doubt our country's international reputation of being a paradise" is likely a circumstance that has 
increased dramatically recently. It resonates with the argument in the book tellingly entitled Even in Sweden: Racisms, Racialized Spaces and the Popular Geographical Imagination (2000), by the human geographer Allan Pred. It is a study of non-European and Muslim immigrants in Sweden who were the target of discrimination in the late twentieth century against a backdrop of global economic restructuring. It is the same observation by Khemiri and Pred: the idea of Sweden as a haven for equal opportunity is obsolete. Still, there is a crucial difference between Pred and Khemiri. In line with standard academic terminology at the time, Pred writes about first and second generation immigrants. Khemiri and his generation, who were born in Sweden and are native speakers of Swedish, see themselves as Swedes. What else would they be?

The debate on racial profiling that began in March 2013 continued for a while. The minister of Justice defended the practice on the radio, and then on television, in an increased effort to find undocumented migrants. There were increased police blockades in an effort to actualize the minister's attempt to locate undocumented immigrants. I still remember clearly and with utter unease the police blocking my subway exit-a wall of tall men dressed in their blue uniforms. As I walked towards them, they stepped aside, opening a gate on my behalf (Wulff 2018:124). With no explanation, one day the blockades suddenly stopped.

\section{Call My Brothers}

Anthropologists are well aware of the complexities of cultural translation. In relation to Khemiri's work, cultural translation also includes an investigation into how fiction is transposed to other genres-an important part of his work, because most of his novels have been turned into films or plays. The novella that was made into the play I Call My Brothers (2016a) is, according to Khemiri in a promotional interview, "a story about a main character trying desperately to act normal and the more he tries the less efficient he is" (Khemiri 2014b). He talks about how he experiences an urge to write the story in relation to "the failed suicide attack in Sweden back in 2010. After that attack there were a number of people in the city who were suspicious even though they had nothing to do with this crime" (Khemiri 2014b).

I mentioned that the play I Call My Brothers (Khemiri 2016a) was first published as an essay in Dagens Nyheter. Here is the opening, in my translation:

I call my brothers and say: Something really sick happened yesterday. Have you heard? A man. A car. Two explosions. Right in the city centre. I call my brothers and say: No, no one died. Or. One died. He died. He who is not our brother. But sure. Some people will try to connect him with us. His name, his origin, his hair color. A good enough resemblance (or not at all).

I call my brothers and say: Beware. Lie low for a couple of days. Lock the door. Close the curtains.

The play I Call My Brothers, too, has been translated into a great many languages and has been performed across Europe in addition to the United States. 
Here I will focus on the 2014 New York staging at the New Ohio Theatre OffBroadway. Two points emerge in relation to the New York staging of the play that explain why this play matters in the United States. The first point is that right after the director Erica Schmidt had read the manuscript, the Boston marathon was bombed. The second point is that Stockholm is far from the only city where racial profiling of people in the streets or on the subway can occur. It is also a feature of New York City, where it is referred to as "Stop and Frisk" (and in London it is "Stop and Search"-other world cities have similar projects). This allows police officers to stop pedestrians and search them for weapons. When it comes to the international success of Khemiri's work, it turns out that it cannot be related only to Sweden or any particular engagement in Swedish culture. It can rather be understood as local versions of the global themes of terrorist crimes and racial profiling. As to the New York adaption of I Call My Brothers, according to the director it was set in New York: "This is a play happening here, right now, in this moment, in this room, with these people, in New York City!" (Wulff 2018:125).

As a review in the magazine Execunt by Molly Grogan (2014) tells us, the play is "beginning the morning after a car bombing in Times Square." The reviewer goes on to write:

That he is Arab or a Muslim is never mentioned and actor Damon Owlia's clothes and speech could place him anywhere in the U.S. It is obvious, however, from the knee-jerk reactions of Amor's friends and family that these born and raised New Yorkers are also members, "brothers," of a certain ethnic group and that the bombing will reverberate on all of them at the degree to which they resemble the still un-apprehended, suspects (Grogan 2014).

In the review, "brothers" is within quotation marks, which I argue refers to the double meaning that the term has more often in the United States than in Sweden-especially that of an ethnic or a black peer. In his capacity as an older brother to two younger brothers, Khemiri did compose the original Swedish text with them in mind. As he has said in an interview: "When I heard about this explosion ... I had this very 'big brother' reaction." He adds: "I wanted to call my brothers and I wanted to give them advice on how to handle a society full of fear, of stereotypes or clichés or ideas of the other" (Khemiri 2014b).

Grogan's review of the New York performance talks about the legacy of 9/11 and the role of the individual:

In I Call My Brothers, Khemiri puts his finger firmly on the unspeakable: racism and fear of the Other in a post 9/11 world. With Brothers, however, he moves his sights from the societies that generate these fears, in Europe and North America, to the objectified individuals internalizing them (Grogan 2014).

Here is the story as told by the reviewer:

When Amor steps out of his apartment building that morning, he believes that he blends in with the Sunday crowds and tourists in Midtown, his jeans and hoodie erasing all suspicion from his thick beard and jet black ponytail. But he is followed almost immediately by an undercover detective, who relays his every move to a command center ... Or is he? (ibid.) 
"One understands implicitly," the reviewer says:

That Khemiri writes from experience as a dual culture, half-Tunisian Swede, growing up speaking Arabic against a milky-white cultural smorgasbord of Abba, Strindberg, and Saint Lucia. If Brothers takes place in New York City, rather than Stockholm, it's an ironic jab: even in the most cosmopolitan city in the world, it is apparently still possible to pick out an Arab terrorist from a city block away (ibid.)

It is true that Khemiri grew up speaking Arabic, but also Swedish as well as French, and that he learned English "in a multi-lingual family in Stockholm" (Khemiri 2015a). Moreover, from the way this reviewer characterizes Sweden, it is clear that she is not really familiar with the country, at least not with contemporary Sweden. In that sense, some things did get lost in this translation, while others were indeed gained. It should be noted that in the United States, the stereotypical "Other" is Mexican, while the enemy within is African American. In Sweden, like in the neighboring countries, the Other is nearly always a Muslim or someone who is taken to be a Muslim because of his (the structural Other is commonly a male) looks. Comparing the United States and Sweden here reveals a similar stereotypical fear in both countries of Muslims as potential terrorists. Whether Khemiri is a Muslim himself does not matter, what matters is that he, and his main character in I Call my Brothers, look like one. This is relevant for Khemiri's reception at home and abroad. While being equated to looking like a terrorist is a familiar experience for large parts of his audiences, it is an eye opener for others.

\section{An "Enigmatic" Novel}

In 2015, Khemiri's novel Everything I Don't Remember was published in Swedish to great, anticipated acclaim. It is the story of Samuel, a young man who is killed in a car crash. But was it an accident or a suicide? An unnamed writer starts his own investigation into Samuel's last day. He talks to friends, relatives, and neighbors, and thus Samuel is pieced together as a person for the reader. Samuel was a devoted grandson, a reluctant bureaucrat at the Migration Board, a loyal friend, but also a skilled poseur. He was totally committed to his girlfriend Laide and shared everything with his best friend Vandad.

Then he disappeared from both of them. We learn that Laide is an interpreter who interprets from Arabic for vulnerable women. When Samuel's grandmother has to move to a retirement home, Samuel and Laide clandestinely use her house as a safe house for women. Disaster hits, and the question of who was responsible for what then puts a strain on the friendship between Vandad and Laide.

The novel won, again, the August Prize for "Best Swedish Fiction Book of the Year." Except for the Nobel Prize, which recognizes a lifetime of literary achievements rather than just one book, the August Prize is the most prestigious literary prize in Sweden. The August jury's rationale for awarding the prize was as follows (in my translation): 
How did Samuel die, and why? Jonas Hassen Khemiri's portrayal of the deceitfulness of memory and testimony is as enthralling as a thriller. But the novel is also a love story and a tale of violence, unforgivable betrayals, and the power of economics. An unconventional narrative structure where several different voices paint the portrait of the protagonist. All written in a sophisticated, toned down prose, where the shadowy existence of undocumented immigrants and criminals collide with the sunny world of privilege in a ruthless and hectic Stockholm (Khemiri 2019b).

In 2017, the Italian translation of Everything I Don't Remember was shortlisted for the Strega Prize, the top literary prize in Italy. ${ }^{5}$ Soon the novel was translated into twenty-five languages. The English translation by Rachel WillsonBroyles (who has translated most of Khemiri's work into English) came first, published in 2016 by Scribner in London. This was the year when Everything I Don't Remember was chosen by Joyce Carol Oates (2016) for being an "enigmatic novel" as a Times Literary Supplement Book of the Year. The "enigmatic" designation recurs in many reviews, not always positively. It is quite often used in the sense of being "obscure," for even though, the English translation and promotions of it display jubilant endorsements (that would have been invited by the press as endorsements usually are), the reviewers in the United States were not really impressed. The novel was not reviewed in major newspapers or literary magazines there. The reason for this lack of interest is most likely that unlike the open letter to the Minister of Justice and the play I Call My Brothers, the novel Everything I Don't Remember could not be directly related to acute situations of terrorism or racism in New York, or to any other societal crises there. It is also possible that the somewhat complex narrative structure with multiple voices that moved back and forth in time was a hindrance to a major success in New York. In addition, there is the question of genre. Marketed as a novel, Everything I Don't Remember has the structure of a mystery-a whodunit in combination with a puzzle full of clues. The novel is definitely not a Nordic Noir (a genre made famous by Henning Mankell's Kurt Wallander books), where the story is told from the police officer's perspective and set in bleak landscapes that suddenly reveal brutal murder and other crimes (see Nilsson, Damrosh and D'haen 2017). Everything I Don't Remember is brilliant, original, and touching, but it cannot compete with other Swedish mysteries and crime fiction that have succeeded in the highly competitive market in the United States.

\section{Final Thoughts}

Let me suggest a final analytical idea for the understanding of Khemiri's work. The Iranian media scholar Hamid Naficy (2001) has coined the notion of an "accented" cinema, referring to the growing film genre that tells stories about experiences of expatriation in the West by filmmakers from other parts of the world than Europe and the United States. Naficy sees these films as "accented" because they include voices from different cinematic traditions, not least exilic and diasporic traditions. This means that "accented" films offer new perspectives to a mainstream audience. This is precisely what Khemiri's work does in the United States but probably even more so in Sweden to an 
audience there (Wulff 2018:127), which Khemiri, in his Open Letter, reminds us is not "a paradise, with equal opportunities for everyone" anymore. This is one side of the impact of the work of Khemiri and his generation of writers. The other side is that they educate a mainstream audience in Sweden about the increasing presence of ethnic diversity as a matter of course. One difference between the two countries is then that readers in the United States would mainly want to learn about the fear of terrorists through Khemiri's work, while Swedish readers are discovering a new, ethnically diverse Sweden and that this is, in the words of anthropologist Roger Sanjek (1998): "the future of us all!"

\section{Notes}

Acknowledgments. This article draws on my research project, "Cosmopolitanizing from Within: Migrant Writers in Sweden," which is a part of the program "Cosmopolitan and Vernacular Dynamics in World Literatures" (funded by the Swedish Foundation for the Humanities and Social Sciences 2016-2021).

1. This article has been presented in earlier versions at the conference, "Loose Tongues: World Literature and the Vernacular," at Stockholm University August 23-25, 2017; and at the Symposium on the Occasion of Andre Gingrich's Retirement from the University of Vienna, November 2-3, 2017.

2. REVA is short for "Rättsäkerhet och effektivt verkställningsarbete," translated as, "Justice security and efficient implementing work." This was a collaboration between the border police, the migration board, and criminal care.

3. The year after the first publication of the open letter (Khemiri 2014a) it was included in the volume Rasismen in Sverige (Racism in Sweden).

4. Named after the influential Swedish writer and dramatist August Strindberg (1894-1912), the annual August Prize is awarded in three genres: Best Swedish Fiction Book of the Year, Best Swedish Non-Fiction Book of the Year, and Best Swedish Children's Book of the Year. Each winner receives 100,000 Swedish Kronor.

5. The prize is called Il Premio Strega Europeo in Italian.

\section{References Cited}

Becker, Howard S. 2008 Art Worlds. Berkeley: University of California Press.

Bourdieu, Pierre 1993 The Field of Cultural Production. New York: Columbia University Press.

Damrosh, David 2003 What Is World Literature? Princeton, NJ: Princeton University Press.

Gingrich, Andre

2015 "Comparative Method in Anthropology." In International Encyclopedia of the Social and Behavioral Sciences. 2nd edition, Volume 4, edited by Neil J. Smelser and Paul B. Baltes, pp. 411-414, Oxford: Pergamon.

Grogan, Molly

2014 "I Call My Brothers: The Faces of Racism." Execunt Magazine, February 5. http://exeuntmagazine.com/reviews/i-call-my-brothers/

Gröndahl, Satu

2007 "Identity Politics and the Construction of Minor Literatures: Multicultural Swedish Literature at the Turn of the Millenium." Multiethnica 30:21-29.

Hannerz, Ulf

1993 "Mediations in the Global Ecumene." In Beyond Boundaries: Understanding, Translation and Anthropological Discourse, edited by Gíslí Pálsson, pp. 41-57. Oxford: Berg. 
Khemiri, Jonas Hassen

1999 "En spärr mot samtal och kontakt." Dagens Nyheter. August 23.

2003 Ett öga rött [One Eye Red]. Stockholm: Norstedts.

2010 I Call My Brothers. https://www.dn.se/kultur-noje/kulturdebatt/jag-ringer-mina-broder/"Jagringer mina bröder". Dagens Nyheter, accessed December 19.

2012 Jag ringer mina bröder. Stockholm: Bonniers.

2013a "Sweden's Closet Racists." New York Times, April 20. Translated by Rachel

Willson-Broyles. https://www.nytimes.com/2013/04/21/opinion/sunday/swede ns-closet-racists.html

2013b "Bästa Beatrice Ask." Dagens Nyheter, March 13.

2014a "Bästa Beatrice Ask." In Rasismen i Sverige: Nyckeltexter 2010-2014, edited by Lawen Mohtadi, and Devrin Mavi, pp. 146-153. Stockholm: Natur \& Kultur.

2014b "I Call My brothers," Promotional Video, theplaycompanynyc, February 9.

2015a “Jonas Hassen Khemiri: Open Letter Goes Viral." BonnierGrid 2015.

2015b Allt jag inte minns. Stockholm: Albert Bonniers förlag.

2016a I Call My Brothers. London: Oberon Books. Translated by Rachel Willson-Broyles.

2016b Everything I Don't Remember. London: Scribner.

2017a “As You Would Have Told It to Me (Sort Of) If We Had Known Each Other Before You Died." New Yorker, September 25.

2017b "Vad är nazister, pappa?" Dagens Nyheter, September 30.

2019a http://www.khemiri.se/en/books/one-eye-red-ett-oga-rott/, accessed February 21.

2019b http://www.khemiri.se/en/books/everything-i-dont-remember-allt-jag-inte-minns//, accessed February 21.

Lundberg, Patrik

2015 "Och här är ett öppet brev till Jonas Hassen Khemiri [And Here is An Open Letter to Jonas Hassen Khemiri]." Aftonbladet, September 24.

Mohtadi, Lawen, and Devrin Mavi, eds.

2014 Rasismen i Sverige: Nyckeltexter 2010-2014 [Racism in Sweden: Key Texts 20102014]. Stockholm: Natur \& Kultur.

Naficy, Hamid

2001 An Accented Cinema: Exilic and Diasporic Filmmaking. Princeton, NJ: Princeton University Press.

Nilsson, Louise, David Damrosh, and Theo D'haen, eds.

2017 Crime Fiction as World Literature. London: Bloomsbury.

Nilsson, Magnus

2010 "Swedish 'Immigrant Literature' and the Construction of Ethnicity." TijdSchrift voor Skandinavistiek 31(1):199-218.

2012 "Swedish 'Immigrant Literature' and the ethnic lens: the representation of cultural diversity in Jonas Hassen Khemiri's 'Ett öga rött. [One Eye Red] and Marjaneh Bakhtiar"s 'Kalla det vad fan du vill' [Call what the hell you want]." Scandinavian Studies 84(1):27-58.

Oates, Joyce Carol

2016 "Books of the Year." Times Literary Supplement, November 23. https://www. the-tls.co.uk/articles/public/books-of-the-year-2016/.

Ortner, Sherry B.

2013 Not Hollywood: Independent Film at the Twilight of the American Dream. Durham, NC: Duke University Press.

Pred, Allan

2000 Even in Sweden: Racisms, Racialized Spaces, and the Popular Geographical Imagination. Berkeley: University of California Press.

Said, Edward

2010 "The Public Role of Writers and Intellectuals." In The Public Intellectual, edited by Helen Small, pp. 19-39. Oxford: Blackwell. 
Sanjek, Roger

1998 The Future of Us All: Race and Neighborhood in New York City. Ithaca, NY: Cornell University Press.

Svedjedal, Johan (ed.)

2013 Svensk litteratur som världslitteratur: En antologi. Avdelningen för litteratursociologi. Uppsala: Uppsala universitet.

Wendelius, Lars

2002 Den dubbla identiteten: Immigrant- och minoritetslitteratur på svenska 1970-2000 [The Double Identity: Immigration Literature in Swedish 1970-2000]. Uppsala: Centrum för Multietnisk forskning.

Wulff, Helena

2017 Rhythms of Writing: An Anthropology of Irish Literature. London: Bloomsbury.

Wulff, Helena

2018 "Diversifying from Within: Diaspora Writings in Sweden." In The Composition of Anthropology: How Anthropological Texts Are Written, edited by Morten Nielsen and Nigel Rapport, pp. 122-136. London: Routledge. 